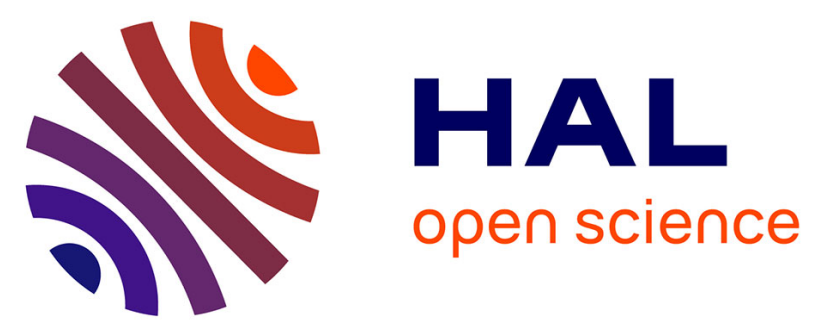

\title{
Time-Resolved In Situ Neutron Diffraction Study of Cu22Fe8Ge4S32 Germanite: A Guide for the Synthesis of Complex Chalcogenides
}

Laura Paradis-Fortin, P. Lemoine, Carmelo Prestipino, Ventrapati Pavan

Kumar, Bernard Raveau, Vivian Nassif, Stéphane Cordier, Emmanuel

Guilmeau

\section{To cite this version:}

Laura Paradis-Fortin, P. Lemoine, Carmelo Prestipino, Ventrapati Pavan Kumar, Bernard Raveau, et al.. Time-Resolved In Situ Neutron Diffraction Study of Cu22Fe8Ge4S32 Germanite: A Guide for the Synthesis of Complex Chalcogenides. Chemistry of Materials, 2020, 32 (20), pp.8993-9000. 10.1021/acs.chemmater.0c03219 . hal-03105509

\section{HAL Id: hal-03105509 \\ https://hal.science/hal-03105509}

Submitted on 11 Jan 2021

HAL is a multi-disciplinary open access archive for the deposit and dissemination of scientific research documents, whether they are published or not. The documents may come from teaching and research institutions in France or abroad, or from public or private research centers.
L'archive ouverte pluridisciplinaire HAL, est destinée au dépôt et à la diffusion de documents scientifiques de niveau recherche, publiés ou non, émanant des établissements d'enseignement et de recherche français ou étrangers, des laboratoires publics ou privés. 


\section{INTRODUCTION}

Solid-state synthesis in sealed tube is one of the fundamentals of inorganic material chemistry. Despite its simplicity, it presents several drawbacks: (i) the long duration (from hours up to days) that strongly depends on the temperature and the type of precursors, (ii) the difficulties in controlling chemical homogeneity, particle size and shape and (iii) the limitation to thermodynamically stable phases. In particular, the synthesis of ternary and quaternary chalcogenide mineral derivative compounds is quite challenging, as the synthesis and crystallization conditions in laboratory are far from the geological processes and durations. Typical synthesis process optimization consists in quenching the reaction at selected times and/or temperatures for ex situ characterization of the samples in order to determine the optimal conditions. ${ }^{-9}$ In addition to being timeconsuming, such method is unsuitable for the detection and determination of quick reactions, as well as short-lived or air-sensitive intermediates. Therefore, the investigation of reaction pathways by in situ analysis has become an emerging field in solid-state chemistry. ${ }^{10-12}$

Real time in situ reaction monitoring is a powerful tool which allows to develop rational synthesis schemes and to better understand the reactions kinetic and mechanism occurring during crystallization sequences. ${ }^{13-22}$ Such experiments have been mainly limited to XRD analyses.

Thanks to the development of dedicated instruments on high flux neutron sources enabling fast data acquisition, ${ }^{23}$ in situ neutron powder diffraction has already been used to study the crystallization of amorphous materials, ${ }^{24,25}$ cationic ordering, ${ }^{26-29}$ mechanical properties, ${ }^{30,31}$ solid-gas reactions,,$^{32-35}$ and chemical processes in batteries. ${ }^{36-39}$ To this day, in situ powder neutron diffraction studies dedicated to sulfide materials have been performed only on pre-reacted or already formed sulfides, ${ }^{40-48}$ mainly to determine their temperature stability and decomposition mechanisms. In spite of the clear advantages of neutrons compared to X-rays (i.e. high penetration depth suited for bulk sample characterization, scattering lengths of the same order of magnitude even for light elements) and magnetic ordering detection, in situ neutron diffraction was never used, to the best of our knowledge, to characterize in real time the successive chemical reactions occurring during sealed tube synthesis of a sulfide from elemental precursors. Such experiments should be of prime interest for the determination and/or optimization of the synthesis conditions, especially in the case of complex compounds as encountered in quaternary sulfide systems.

In this study, we monitored for the first time the natures and crystal structures of the intermediate phases formed ACS Paragon Plus Environment 
during the solid-liquid-gas reactions of a quaternary sulfide, germanite $\mathrm{Cu}_{22} \mathrm{Fe}_{8} \mathrm{Ge}_{4} \mathrm{~S}_{32}$. Using time-resolved in situ neutron powder diffraction data, we analyzed the successive chemical reactions as a function of temperature, and determined the key conditions to produce high purity samples. Such simple approach and methodology can provide guidance for the synthesis of many complex chalcogenides with the aim to design new efficient materials for various types of applications for energy harvesting and storage (photovoltaic, batteries, thermoelectric...).

\section{EXPERIMENTAL SECTION}

Synthesis. Cu (99 at.\%, Alfa Aesar), Fe (99.5 at.\%, Alfa Aesar), Ge (99.999 at.\%, Alfa Aesar) and S (99.5 at.\%, Alfa Aesar), all commercial powders, were stored and manipulated in a glove box under argon atmosphere. The powders were weighed in a stoichiometric ratio $(22 \mathrm{Cu}: 8 \mathrm{Fe}: 4 \mathrm{Ge}: 32 \mathrm{~S})$ and ground together in an agate mortar. The $1.5 \mathrm{~g}$ batches of powder were then pressed into $5 \mathrm{~mm}$ diameter pellets. The pellets were placed in silica tubes $\left(\phi_{\mathrm{ext}}=8 \mathrm{~mm}, \phi_{\text {int }}=6 \mathrm{~mm}\right)$ evacuated down to a pressure of $\approx 10^{-2}$ mbar from an argon atmosphere. The tubes were sealed as close as possible to the sample to maximize the sample/silica weight ratio. Those tubes were used for in situ time resolved neutron powder diffraction.

In addition, the optimized synthesis conditions of $\mathrm{Cu}_{22} \mathrm{Fe}_{8} \mathrm{Ge}_{4} \mathrm{~S}_{32}$ germanite sample, determined from neutron powder diffraction analyses, were reproduced in laboratory. Sealed tubes were placed in a tubular furnace in vertical position with a heating rate of $2 \mathrm{~K} \mathrm{~min}^{-1}$ and a plateau at $973 \mathrm{~K}$ for $24 \mathrm{~h}$. The samples were cooled down to $773 \mathrm{~K}$ at a natural cooling rate by switching off the heat power of the furnace, and then air quenched.

Differential scanning calorimetry and thermogravimetric analysis. Phase transitions and weight losses were investigated by differential scanning calorimetry (DSC) and thermogravimetric analysis (TGA) respectively, using a Netzsch $404 \mathrm{~F}_{3}$ Pegasus apparatus. TGA-DSC measurements were carried out on a powder sample of reacted germanite from room temperature (RT) up to $973 \mathrm{~K}$ at the rate of $2 \mathrm{~K} \mathrm{~min}^{-1}$ under argon flow to avoid oxidization of the sample. The raw data were not corrected for instrumental contributions.

$\mathrm{X}$-ray and neutron powder diffraction. The purity and the crystal structure of the germanite samples prepared in laboratory were checked by X-ray powder diffraction (XRPD). High-resolution data were collected using a Bruker D8 Advance Vario 1 fitted with a two-circle diffractometer $(\theta-2 \theta$ Bragg-Brentano mode) equipped with a $\mathrm{Cu} \mathrm{K} \alpha_{1} \mathrm{X}$-ray tube, a Ge [111] monochromator and a LynxEye detector. Thermal stability investigations were carried out by XRD on a germanite powder sample obtained by sealed tube (ST) synthesis. Measurements were carried out between RT and $1000 \mathrm{~K}$ on powder in a glass capillary sealed under vacuum. The diffractograms were collected every $50 \mathrm{~K}$ during $2 \mathrm{~h}$ isotherms $(4 \times 30 \mathrm{~min})$ using a Bruker D8 advance diffractometer in Debye-Scherrer configuration equipped with a Mo K $\alpha$ source, a focusing multilayer mirror, a set of radial Soller slits and a LynxEye XE detector.
Time resolved in situ neutron powder diffraction (NPD) experiments were performed at the Institut Laue Langevin (ILL, Grenoble, France). The high temperature data were acquired on the high intensity two-axis powder DıB diffractometer, equipped with a vanadium furnace and a $3 \mathrm{He}$ multi detector ( 1280 cells) covering a $128^{\circ}$ angular range in a Debye-Scherrer geometry. Sealed silica tubes containing the elemental precursors were irradiated by the neutron beam $(\lambda$ = 1.284(1) $\AA$, refined using a standard compound), equipped with a Ge [311] monochromator. A first set of neutron powder diffraction (NPD) data was collected every 2.5 minutes from RT up to $973 \mathrm{~K}$ at a heating rate of $2 \mathrm{~K} \mathrm{~min}^{-1}$ (one pattern every $5 \mathrm{~K}$ ), with $1 \mathrm{~h}$ isotherm at $675 \mathrm{~K}$ and $1.5 \mathrm{~h}$ isotherm at $973 \mathrm{~K}$, followed by a fast cooling down to RT by furnace-quenching (switching off the power). A second set of NPD data was collected every 5 minutes from RT up to $973 \mathrm{~K}$ at a heating rate of $2 \mathrm{~K} \mathrm{~min}^{-1}$ (one pattern every $10 \mathrm{~K}$ ), with $1 \mathrm{~h}$ isotherm at 973 $\mathrm{K}$, and from $973 \mathrm{~K}$ down to $\mathrm{RT}$ at a cooling rate of $2 \mathrm{~K} \mathrm{~min}^{-1}$ (one pattern every 10 $\mathrm{K}$ ). The temperature profiles are displayed in Figures $\mathbf{S} \mathbf{1}$ and $\mathbf{S} \mathbf{2}$, respectively. The $\mathbf{1} \mathbf{h}$ isotherm at $675 \mathrm{~K}$ in the former experiment was applied to limit the risk of explosion of the sealed silica ampoule, sometimes observed if uncontrolled exothermic reaction occurs between sulfur and metallic elements. From this experiment, it was shown that sulfur reacts with metallic elements well below $675 \mathrm{~K}$ (see below), consequently, this isotherm was not considered in the second in situ NPD experiment. Note that, with the second temperature profile, the sample temperature deviates from the set temperature below $580 \mathrm{~K}$ due to the furnace inertia. Considering the distance between the thermocouple and the sample and the duration of data acquisition $\left(2.5 \mathrm{~K} \mathrm{~min}^{-1}\right.$ or $5 \mathrm{~K}$ $\left.\mathrm{min}^{-1}\right)$, the estimated error on the temperature is about $\pm 10 \mathrm{~K}$. Refinements of the diffraction patterns (XRPD and NPD) were performed by Le Bail and Rietveld methods using the FullProf and WinPlotr software packages, ${ }^{49,50}$ with a manually selected background (mandatory due to the noisy background from silica contribution).

\section{RESULTS AND DISCUSSION}

Time-resolved in situ neutron diffraction. Heating. In situ NPD patterns were recorded every $5 \mathrm{~K}$ from RT up to $973 \mathrm{~K}$ (heating rate of $2 \mathrm{~K} \mathrm{~min}^{-1}, 2.5 \mathrm{~min}$ per pattern), with an isotherm of $1 \mathrm{~h}$ at $675 \mathrm{~K}$. Before heating, a diffraction pattern was recorded during $1 \mathrm{~h}$ in order to determine the starting products (Figure $\mathbf{S}_{\mathbf{3}}$ ). Rietveld refinement indicates the presence of the elementary components, $\mathrm{Cu}(F m \overline{3} m, a=3.6 \mathrm{o}(8) \AA)$, Fe $(\operatorname{Im} \overline{3} m, a=$ 2.86(7) $\AA$ ), Ge $(F d \overline{3} m, a=5.64(7) \AA), \alpha-\mathrm{S}_{8}(F d d d, a=$ 10.41(7) $\AA, b=12.89(4) \AA, c=24.35(1) \AA)$, and of CuS $\left(P 6_{3} /\right.$ $m m c, a=3.78(3) \AA, c=16.32(9) \AA)$. Note that CuS is likely formed during the sealing of the silica tube. Due to the semi-amorphous nature of the silica tube, all the diffraction patterns have a noisy background that hinders the possibility to reliably quantify the phases by Rietveld refinement.

The NPD patterns collected during the heating ramp from RT to $973 \mathrm{~K}$ are presented in Figure 1 in a $2 \mathrm{D}$ contour plot between $20^{\circ}-50^{\circ}$ in $2 \theta$. The sequence of diffractograms could be divided in seven intervals characterized by the formation of the successive secondary, ternary and quaternary compounds. For the 
sake of clarity, the phases are named according to their chemical formula although it does not necessarily represent their real final stoichiometry. The nature of each phase was determined by Rietveld refinement of the NPD patterns acquired at specific temperatures, i.e. the transition temperatures $(T=300 \mathrm{~K}, 430 \mathrm{~K}, 530 \mathrm{~K}, 590 \mathrm{~K}$, $640 \mathrm{~K}, 770 \mathrm{~K}, 840 \mathrm{~K}$ and $973 \mathrm{~K})$ and in-between $(T=480 \mathrm{~K}$, $575 \mathrm{~K}, 615 \mathrm{~K}, 675 \mathrm{~K}$ and $810 \mathrm{~K})$.

In the first temperature region, from $300 \mathrm{~K}$ to $430 \mathrm{~K}$, the diffraction peaks of $\alpha-S_{8}$ disappear close to its melting temperature (not observable on Figure 1 due to weak intensities) indicating the solid to liquid transition of the element, while $\mathrm{Cu}, \mathrm{Fe}, \mathrm{Ge}$ and $\mathrm{CuS}$ peaks remain unchanged. Above $430 \mathrm{~K}$, the second region is characterized by the appearance of covellite $\mathrm{CuS}$, concomitantly with the disappearance of $\mathrm{Cu}$ diffraction peaks suggesting the reaction of liquid sulfur with metallic copper (Figure $\mathbf{S}_{4}$ ). At $490 \mathrm{~K}$, a reaction between sulfur and iron occurs leading to the decrease of the peak intensity of $\mathrm{Fe}$ and the appearance of $\mathrm{FeS}\left(P 6_{3} m c, \mathrm{a} \sim 7.0\right.$ $\AA$, c $5.6 \AA$ ) diffraction peaks. Starting from $530 \mathrm{~K}$, the third temperature interval is characterized by the formation of $\mathrm{CuFeS}_{2}$ chalcopyrite $(I \overline{4} 2 d)$ (Figure $\left.\mathbf{S}_{5}\right)$. Concomitantly, the intensity of the diffraction peaks of $\mathrm{Fe}$ strongly decreases up to $590 \mathrm{~K}$, while it slightly decreases for $\mathrm{CuS}$. Considering that the peaks intensity of the FeS phase remains constant from $530 \mathrm{~K}$ to $590 \mathrm{~K}$, it suggests that Fe reacts with $\mathrm{CuS}$ to form $\mathrm{CuFeS}_{2}$ chalcopyrite $(I \overline{4} 2 d$, $\mathrm{a} \sim 5.2 \AA, \mathrm{c} \sim 10.4 \AA$ ). Hence, at $590 \mathrm{~K}, \mathrm{Cu}$ and Fe have totally reacted with $\mathrm{S}$ to form $\mathrm{CuS}, \mathrm{FeS}$ and $\mathrm{CuFeS}_{2}$ binary and ternary phases, while Ge remains in its elementary state (Figure $\mathrm{S}_{5}$ ). Above $590 \mathrm{~K}$, the contents of $\mathrm{CuS}, \mathrm{FeS}$ and $\mathrm{CuFeS}_{2}$ decrease up to $640 \mathrm{~K}$, progressively replaced by pyrite $\mathrm{FeS}_{2}(P a \overline{3}, \mathrm{a} \sim 5.4 \AA)$, nukundamite $\mathrm{Cu}_{0.85} \mathrm{Fe}_{0.15} \mathrm{~S}(P \overline{3} m$ $1, \mathrm{a} \sim 3.8 \AA, \mathrm{c} \sim 11.2 \AA)$, and bornite $\mathrm{Cu}_{5} \mathrm{FeS}_{4}(\mathrm{Fm} \overline{3} m, \mathrm{a} \sim 5.5$ $\AA$ ) (Figure S6). These observations are consistent with the stability of chalcopyrite $\mathrm{CuFeS}_{2}$ and pyrrhotite FeS up to 600 K. ${ }^{1}$ The formation of bornite $\mathrm{Cu}_{5} \mathrm{FeS}_{4}$ starts around $\sim 575 \mathrm{~K}$. Its identity was later confirmed by Rietveld refinements (at higher temperature) and by its characteristic topotactic transition temperatures during

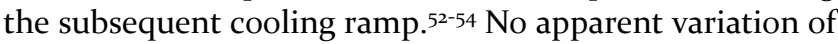
the peaks intensity was detected from $640 \mathrm{~K}$ up to $770 \mathrm{~K}$ (Figure 1).

Above $770 \mathrm{~K}$, the diffraction peaks of nukundamite $\mathrm{Cu}_{0.85} \mathrm{Fe}_{0.15} \mathrm{~S}$ disappear, while the peaks intensity of bornite $\mathrm{Cu}_{5} \mathrm{FeS}_{4}$ drastically increases (Figure $\mathrm{S}_{7}$ ), indicating the decomposition of nukundamite into a bornite phase probably associated with the formation of digenite $\mathrm{Cu}_{1.8} \mathrm{~S}$. This observation agrees with data reported in the literature. ${ }^{51}$ Additionally, one can note the appearance at $810 \mathrm{~K}$ of an unidentified diffraction peak (marked by a question mark) concomitant with the slow fading of pyrite $\mathrm{FeS}_{2}$ and Ge diffraction peaks, until its total disappearance between $840 \mathrm{~K}$ and $860 \mathrm{~K}$ (Figure $\mathrm{S}_{7}$ and Figure S8). Finally, the first quaternary phase (HT_quat) appears above $840 \mathrm{~K}$ from the reaction of Ge with the ternary phases, e.g. nukundamite and bornite (Figure S8). Experimentally, the heating ramp was followed by an isotherm of 90 min at $973 \mathrm{~K}$, where the content of HT_quat phase increases slowly at the expense of bornite during the first 6o min (Figure S9). It indicates that the formation of the high temperature quaternary phase was completed during the isotherm.

From the present data, it is quite difficult to determine the crystal system of the high temperature quaternary (HT_quat) phase: it can be either a high temperature disordered cubic form of the expected germanite compound or an intermediate phase with lower symmetry and different unit cell parameters. From the position of the reflection peaks and their relative intensities, it is obvious that the HT_quat phase has a metric close to cubic germanite $(P \overline{4} 3 n)$, but it is also true for many quaternary compounds. Unfortunately, the experimental setup prevents to discriminate between cubic and tetragonal cell, as the resolution is not sufficient to detect eventual peak splitting, representative of a tetragonal symmetry.

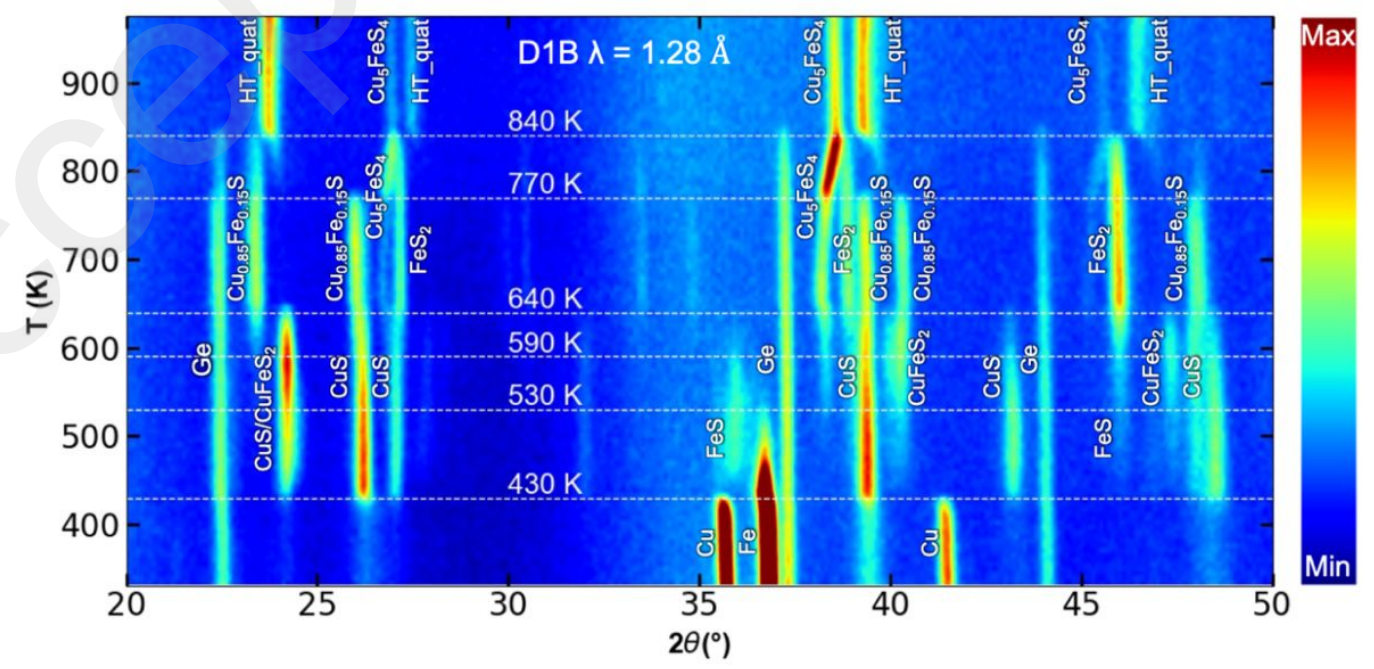

Figure 1. 2D contour plot showing the NPD patterns of the in situ sealed tube reaction from elemental precursors 
Tetragonal $P \overline{4} 2 c$ space group, as found in renierite, 55 is a maximal translationengleiche subgroup of the cubic space group found in germanite $(P \overline{4} 3 n)$. Yet, the experimental conditions did not allow to detect the presence (or absence) of the renierite structure. Thus, a briartite phase $(I \overline{4} 2 \mathrm{~m})^{56}$ was used for the refinement of the HT_quat phase as it generates fewer reflections than renierite $(P \overline{4} 2 c)$ and hence lowers the risk of an artificially low $\chi^{2}$ factor. Figure 2a shows how the supplementary reflections allowed by the $P \overline{4} 2 c$ space group, which are extinguished in the calculated intensity profile of renierite, artificially improves the $\chi^{2}$ factor from 1004 for $I \overline{4} 2 m$ to 700.9 for $P \overline{4}$ $2 c$ (Table S1). Additionally, a closer look at the peak shape reveals a wide Gaussian tail on the right of the reflection peaks 440 and 622 while the 222 reflection peak is not affected. It suggests that only reflections influenced by a cubic to tetragonal deformation have this peak shape anomaly. One origin of the peak broadening is the distribution of the cell parameters induced by microdeformations, which lead to microstrains. While isotropic microstrain produces a $\tan \theta$ dependent broadening, an additional $h k l$-dependence suggests that the microstrain is anisotropic. Although both isotropic and anisotropic strain models adequately describe the peak profile of the 222 reflection (Figure 2b), that of 440 (Figure 2c) was greatly improved by applying Stephens anisotropic microstrain model (pink). ${ }^{57}$ The standard isotropic strain model (blue) slightly underestimates the width of the 440 peaks. In the case of an anisotropic strain of a cubic space group ( $P \overline{4} 3 m$ red, $P \overline{4} 3 n$ yellow, Figure 2d), the broadening would be symmetrical on both sides of the peak, thus excluding this option. The parameters used for these refinements are gathered in Table $\mathbf{S} \mathbf{1}$.

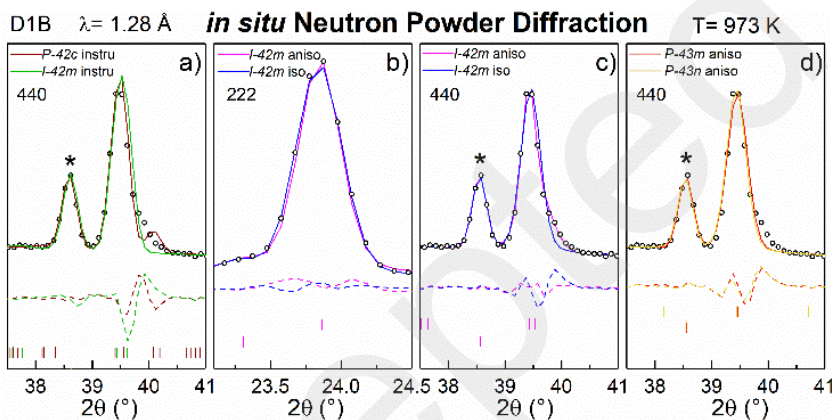

Figure 2. Different Le Bail fits of the NPD isotherm at $973 \mathrm{~K}$ of the HT_quat phase: a) $P \overline{4} 2 c$ (brown) and $I \overline{4} 2 m$ (green) refined with instrument resolution parameter only, b) and c) $I$ $\overline{4} 2 m$ refined with an isotropic (blue) and anisotropic (pink) strain for reflections 222 and 440, respectively and d) $P \overline{4} 3 m$ (red) and $P \overline{4} 3 n$ (yellow) refined with an anisotropic strain. An asterisk pinpoints a contribution of the high temperature form of bornite $\mathrm{Cu}_{5} \mathrm{FeS}_{4}$.

Stephens microstrains model largely captures the anisotropy of the broadening determined by individual fits and induces a clear improvement of the peak shape fitting. Furthermore, it would be interesting to verify the presence of such microdeformations by transmission electron microscopy, but it is technically impossible since this phase only exists at high temperature (above $860 \mathrm{~K}$ ). To yield the sample utmost closely related to the HT composition, a sealed tube was air quenched at $973 \mathrm{~K}$ in laboratory. The diffraction pattern is clearly not that of a pure cubic sample due to the splitting of the peaks at $\sim 34.0^{\circ}, \sim 48.5^{\circ}$ and $\sim 58.0^{\circ}$ (Figure S1o). However, it is also not the diffraction pattern expected for a pure tetragonal sample as the relative intensities of the diffraction peaks deviate from the expected 2:1 ratio for a tetragonal symmetry, notably for the 440 and 622 reflections. Thus, the refinement of this diffraction pattern requires to consider a mixture of tetragonal and cubic phases with the same metric. The $a / c$ ratio of the tetragonal phase is $\sim 1.006$, which is expected for a renierite phase..$^{8}$ These results are in favor of the coexistence of both tetragonal and cubic phases at 973 K. Finally, the absence of superstructure reflections on both NPD pattern at $973 \mathrm{~K}$ (Figure S9) and XRPD pattern after quenching (Figure S1o) can be explained by the quench at high temperature which may induce cationic disorder.

Cooling. The cooling conditions were investigated in real time by in situ neutron powder diffraction in two separate experiments: a quench at $973 \mathrm{~K}$ and a controlled cooling at the rate of $2 \mathrm{~K} \mathrm{~min}^{-1}$. For both cooling pathways, the same main phase was obtained at RT (Figures S11a and S11b), the only difference results in the presence of $\mathrm{Cu}_{5} \mathrm{FeS}_{4}$ (bornite HT cubic form) along with an unknown phase in the quenched sample. The presence of superstructure peaks at low angle (Figures S11a and S11b, first inset on the left), and the absence of splitting of the reflection 800 (Figure S11a and S11b, inset on the right), indicate the formation of germanite and the absence of renierite, respectively.

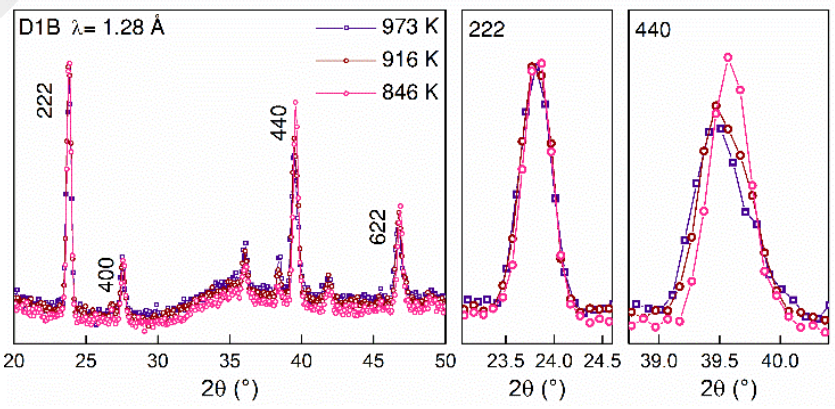

Figure 3. NPD patterns acquired during controlled cooling (2 $\mathrm{K} \mathrm{min}^{-1}$ ) at $973 \mathrm{~K}, 916 \mathrm{~K}$ and $846 \mathrm{~K}$, showing the change from tetragonal to cubic structure during cooling.

The next paragraph describes the changes in the diffractograms measured during the controlled cooling (2 $\left.\mathrm{K} \mathrm{min}^{-1}\right)$. The noisy background of the patterns acquired during the cooling ramp (due to a short collection time and silica contribution) together with the shrinking cell parameters, both consequences of the NPD in situ experiment conditions, hinder the refinement of the anisotropic microstrain parameters. Thus, the structural changes during the cooling ramp will be described using a qualitative approach. During controlled cooling, the first observable change is related to the 440 peak profile, which evolves from a well-defined doublet at $973 \mathrm{~K}$ to a thinner single peak at $846 \mathrm{~K}$ passing through a broad "single" peak 
at $916 \mathrm{~K}$ (Figure 3 ). This peak profile evolution suggests the appearance of a cubic phase, with possibly a different composition, besides the tetragonal one as the temperature decreases from $973 \mathrm{~K}$ to $846 \mathrm{~K}$. The broadening of the "single" peak at $916 \mathrm{~K}$ can be attributed to cationic disorder and/or to the coexistence of both cubic and tetragonal phases.59,60 The second observable change is the emergence of a peak at $25.9^{\circ}$ in the temperature range $860 \mathrm{~K}-820 \mathrm{~K}$. This peak can be attributed to the superstructure reflection 321 of germanite (Figure S12), indicating that the cubic phase formed between $916 \mathrm{~K}$ and $846 \mathrm{~K}$ is germanite. All superstructure peaks should be observed simultaneously, but the noisy background coupled to the intrinsically low intensity of the superstructure peaks make their detection rather difficult. The 321 is the first germanite superstructure peak detected due to its higher angle $\left(25.8^{\circ}\right)$, where the silica contribution to the background is lower. Finally, the third observable change is the anomalous broadening of the main peaks base, observed while cooling the sample below $770 \mathrm{~K}$ (Figure S13) and attributed to the appearance of a low crystallinity sphalerite derivative phase. The formation of this phase below $770 \mathrm{~K}$ limits the possibility to obtain a pure $\mathrm{Cu}_{22} \mathrm{Fe}_{8} \mathrm{Ge}_{4} \mathrm{~S}_{32}$ germanite sample by using a slow cooling down to room temperature despite the apparent high purity of the sample obtained using controlled cooling conditions (Figure S11a).

Following these new insights on germanite crystallization and neighboring phases formation and stability, an optimized sealed tube synthesis route was proposed for $\mathrm{Cu}_{22} \mathrm{Fe}_{8} \mathrm{Ge}_{4} \mathrm{~S}_{32}$ germanite: heating at $973 \mathrm{~K}$ for $24 \mathrm{~h}$, cooled down to $773 \mathrm{~K}$ at a natural cooling rate by switching off the power of the furnace and then air quenched. With these optimized conditions, a high purity germanite sample of 5 grams was prepared by sealed tube synthesis (Figure 4). Its thermoelectric properties after densification either by spark plasma sintering or hot pressing were recently reported and compared to those of germanite sample prepared by mechanical alloying. ${ }^{61}$

Thermal stability of germanite. Considering the difficulty to prepare a high purity germanite sample, due to the easy formation and stability of neighboring phases, it is important to acknowledge the thermal stability of germanite as well as its reactivity zones and products of decomposition. For that matter, a TGA-DSC analysis and XRPD measurements in temperature were performed on a high purity sample of $\mathrm{Cu}_{22} \mathrm{Fe}_{8} \mathrm{Ge}_{4} \mathrm{~S}_{32}$ germanite prepared by optimized sealed tube synthesis.

On the TGA curve (Figure 5), slope changes are observed at $650 \mathrm{~K}$ and $870 \mathrm{~K}$, both referring to an increase in sulfur loss ( $\sim 0.5$ wt. $\%$ at $650 \mathrm{~K}$ and $\sim 3.1 \mathrm{wt}$. \% at $870 \mathrm{~K})$. The DSC curve exhibits a broad endothermic signal starting at $\sim 870 \mathrm{~K}$, which coincides with the second slope change on the TGA curve, suggesting an evolution of the germanite sample above this temperature.

The X-ray diffractograms, recorded from RT to $1000 \mathrm{~K}$ on powder sample in a glass capillary sealed under vacuum (2 $\mathrm{h}$ isotherms, every $50 \mathrm{~K}$ ), are displayed in Figure 6. Due to presence of two spurious peak at $\sim 7^{\circ}$ and $\sim 11^{\circ}$ caused by the furnace window contribution ( $\mathrm{Al}$ foil), the detection of the superstructure peaks was mainly limited to the 211 and 321 reflections. The thermodiffractograms exhibit two main events at $\sim 650 \mathrm{~K}$ and at $\sim 900 \mathrm{~K}$ (Figure 6$)$. The first one, occurring around $650 \mathrm{~K}$, is related to the increase of the diffraction peak at $\sim 21^{\circ}$ indicating the formation of bornite $\mathrm{Cu}_{5} \mathrm{FeS}_{4}$ phase in its high temperature cubic form. This secondary phase formation can be related with the first step of sulfur volatilization detected by TGA above 650 $K$ (Figure 5). It indicates that the first step of sulfur volatilization during high temperature exposure of germanite leads to the formation of the copper-rich $\mathrm{Cu}_{5} \mathrm{FeS}_{4}$ phase $\left(\mathrm{M}_{\mathrm{tot}} / \mathrm{S}\right.$ ratio of 1.5) instead of sulfur deficient germanite derivative $\left(\mathrm{M}_{\mathrm{tot}} / \mathrm{S}\right.$ ratio $\left.\leq 1.0625\right)$.

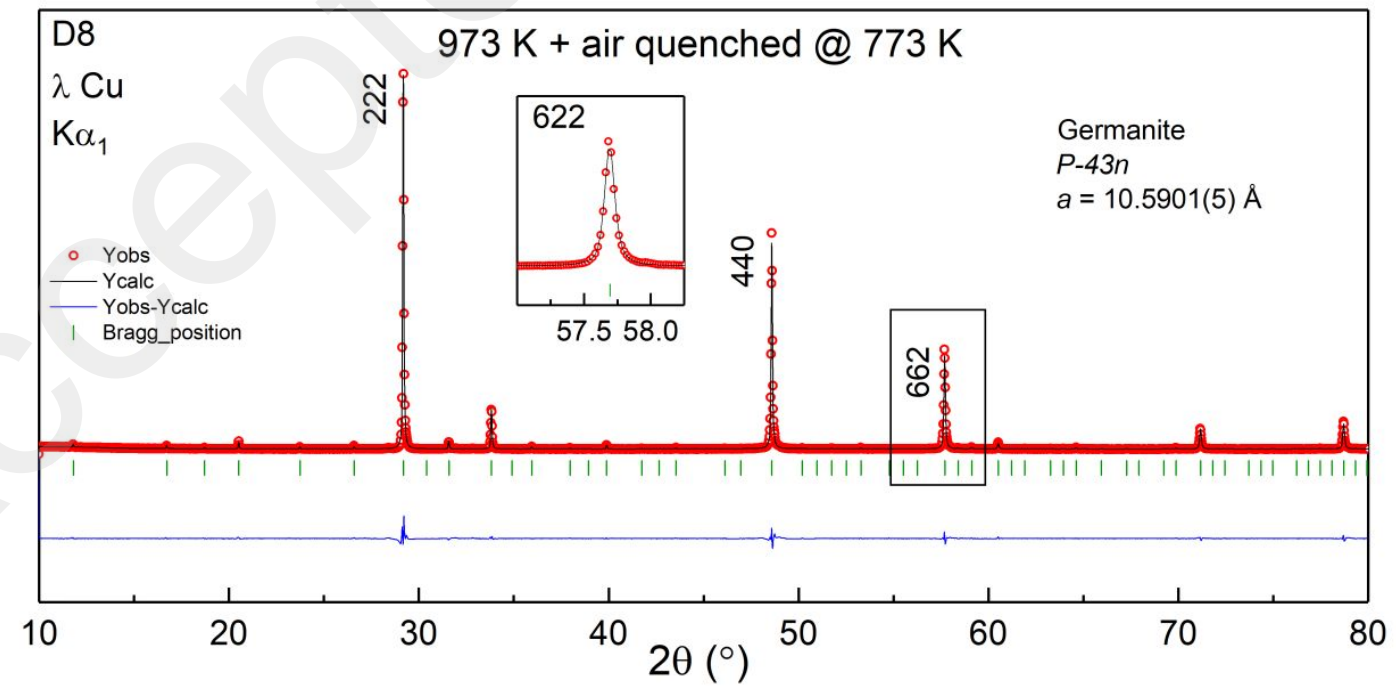

Figure 4. Refinement of the XRPD pattern measured at room temperature of a germanite sample prepared by optimized sealed tube synthesis. 


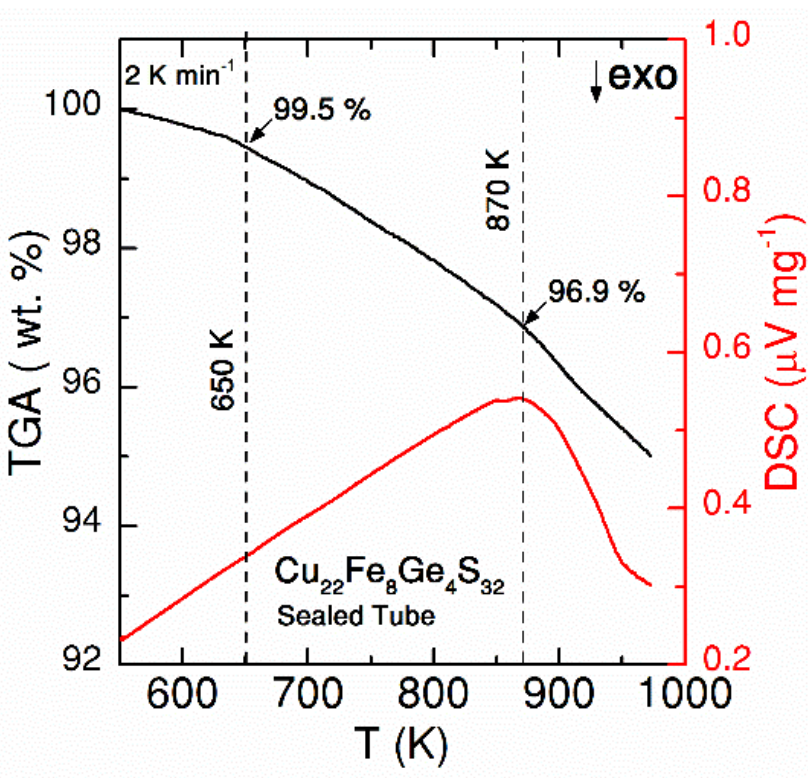

Figure 5. TGA-DSC curves of a germanite $\mathrm{Cu}_{22} \mathrm{Fe}_{8} \mathrm{Ge}_{4} \mathrm{~S}_{32}$ sample in a platinum pan.

The second modification, occurring around $900 \mathrm{~K}$ is related to the disappearance of the superstructure peaks 211 and 321 of germanite, concomitantly with the appearance of new peaks next to the 440 and 622 reflections. This pattern modification through the disappearance/appearance of diffraction peaks is the signature of the change of the cubic germanite structure to a closely related tetragonal structure as the temperature is increased, but with a different chemical composition. A similar structural evolution was previously observed for the $\mathrm{Zn}$ for $\mathrm{Cu}$ substitution in the germanite-renierite series $\mathrm{Cu}_{22-\mathrm{x}} \mathrm{Zn}_{\mathrm{x}} \mathrm{Fe}_{8} \mathrm{Ge}_{4} \mathrm{~S}_{32},{ }^{62}$ where the cubic germanite transforms into the tetragonal renierite as $x$ is increased. Indeed, such structural modification from cubic to tetragonal structure induces the splitting of equivalent reflections into two reflections for the $h h l$ and $h k k$ reflections allowed by the cubic space group, e.g. 440 and 622 , or into three reflections for the $h k l$ reflections. ${ }^{62}$ However, in the present case, the formation of the tetragonal phase is not induced by direct element substitution, but is indirectly related to the sulfur loss, as detected by TGA above $870 \mathrm{~K}$ (Figure 5). Indeed, as shown in the first part of germanite sample evolution, sulfur volatilization induces the formation of the copper-rich phase $\mathrm{Cu}_{5} \mathrm{FeS}_{4}$ bornite, and consequently, it results in a modification of the germanite structure and composition due to the germanium enrichment. This germanium enrichment is most probably the reason of the high temperature phase change from cubic germanite to tetragonal renierite structure (Figure $\mathbf{S 1 4}$ ).

By considering that a chemical composition modification of germanite phase induced by sulfur volatilization at high temperature should modify significantly its unit cell parameter evolution, a second XRPD experiment was performed from room temperature up to $860 \mathrm{~K}$, i.e. below the temperature of modification from cubic to tetragonal structure (Figure S15). The thermal evolution of the unit cell parameter of germanite obtained from refinement of the patterns by the Le Bail method is shown in Figure 7. The linear evolution of the unit cell of germanite up to $650-700 \mathrm{~K}$ demonstrates its good chemical stability in this temperature window. The steeper slope above $650 \mathrm{~K}$, supported by sulfur volatilization above $650 \mathrm{~K}$ (Figure 5), suggests a chemical variation (i.e. cationic disordering and/or composition variation) within the crystal, as already shown in structurally related colusites. ${ }^{48,63-65}$ Moreover, this experiment shows that, at $860 \mathrm{~K}$, the superstructure peaks of germanite were still present and that the cubic to tetragonal phase transformation is not yet achieved (Figure S15).

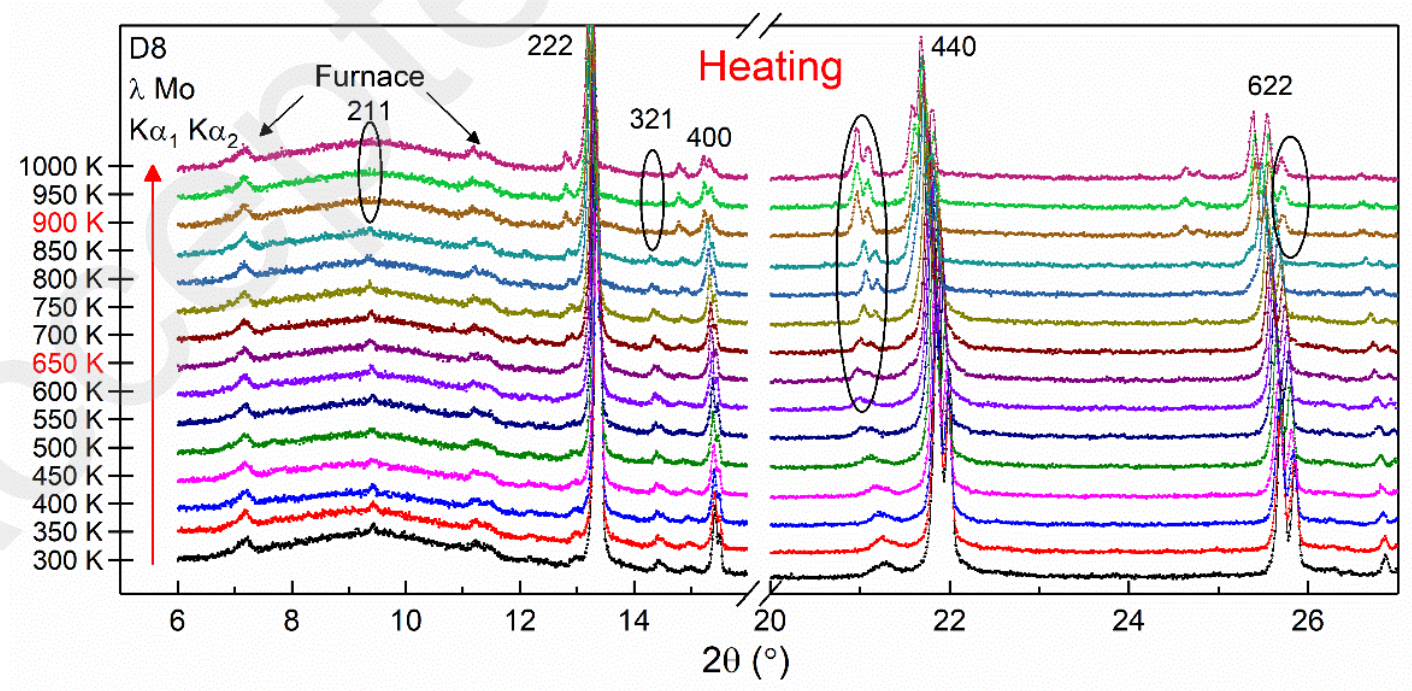

Figure 6. X-ray thermodiffractograms of germanite $\mathrm{Cu}_{22} \mathrm{Fe}_{8} \mathrm{Ge}_{4} \mathrm{~S}_{32}$ from RT to $1000 \mathrm{~K}(\lambda=0.71 \AA$ ) 


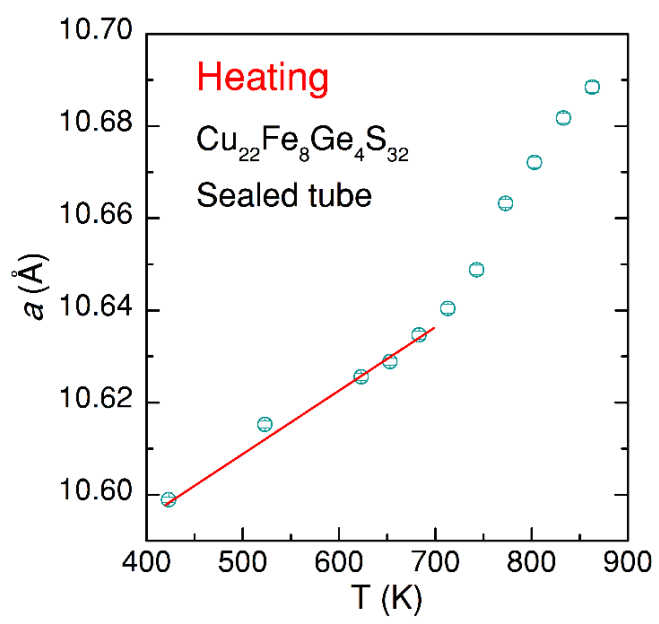

Figure 7. Thermal evolution of the unit cell parameter of germanite $\mathrm{Cu}_{22} \mathrm{Fe}_{8} \mathrm{Ge}_{4} \mathrm{~S}_{32}$ from Le Bail refinement of the XRD patterns recorded up to $860 \mathrm{~K}$. Red line is just a guide for eyes.

Thus, from the interpretation of the combined thermal analyses we can conclude that (i) $\mathrm{Cu}_{22} \mathrm{Fe}_{8} \mathrm{Ge}_{4} \mathrm{~S}_{32}$ germanite is chemically stable up to $650 \mathrm{~K}$ in inert atmosphere, (ii) above $650 \mathrm{~K}$, a weak sulfur volatilization leads to the formation of $\mathrm{Cu}_{5} \mathrm{FeS}_{4}$ bornite and to a germanium enrichment of the germanite phase, and (iii) a cubic to tetragonal phase transformation occurs above $860 \mathrm{~K}$, most probably related to the Ge enrichment of germanite.

\section{CONCLUSION}

This work demonstrates that in situ neutron powder diffraction is an efficient tool for the real-time determination of the natures and crystal structures of the intermediate phases occurring during sealed tube synthesis of complex sulfide materials. This study especially highlights the importance of the synthesis temperature and cooling method on the formation of high purity germanite $\mathrm{Cu}_{22} \mathrm{Fe}_{8} \mathrm{Ge}_{4} \mathrm{~S}_{32}$ sample. The investigation of the phase stability of $\mathrm{Cu}_{22} \mathrm{Fe}_{8} \mathrm{Ge}_{4} \mathrm{~S}_{32}$ shows that the formation of bornite is related to sulfur volatilization happening above $650 \mathrm{~K}$. Also, it demonstrates that cubic germanite is highly sensitive to sulfur volatilization and transforms to a closely related tetragonal phase similar to renierite between $860 \mathrm{~K}$ and $900 \mathrm{~K}$, due to germanium enrichment. This real-time investigation by in situ NPD can be easily applied to study and to optimize the synthesis conditions of other ternary and quaternary chalcogenides and opens the route to the discovery of new materials.

\section{ASSOCIATED CONTENT}

Supporting Information. Temperature profiles of in situ neutron powder diffraction experiments, detailed neutron and X-ray powder diffraction patterns, and specifications of the refinements with isotropic and anisotropic strain models. This material is available free of charge via the Internet at http://pubs.acs.org.

\section{AUTHOR INFORMATION}

\section{Corresponding Author}

* (P. Lemoine) E-mail: pierric.lemoine@univ-rennesı.fr

* (E. Guilmeau) E-mail: emmanuel.guilmeau@ensicaen.fr

\section{Author Contributions}

The manuscript was written through contributions of all authors. All authors have given approval to the final version of the manuscript.

\section{ACKNOWLEDGMENT}

The authors gratefully thank S. Djellit, T. Barbier, and J. Lecourt for technical assistance, the Institut Laue Langevin (Grenoble, France) for the provision of research facilities (doi:10.5291/ILL-DATA.5-24-615 and doi:10.5291/ILLDATA.CRG-2585), and the financial support of the French Agence Nationale de la Recherche (MASSCOTE, 2016, ANR15-CE05-0027) and Normandy Region.

\section{REFERENCES}

(1) Baláž, M.; Zorkovská, A.; Urakaev, F.; Baláž, P.; Briančin, J.; Bujňáková, Z.; Achimovičová, M.; Gock, E. Ultrafast Mechanochemical Synthesis of Copper Sulfides. RSC Adv. 2016, 6 (91), 87836-87842.

(2) Barbier, T.; Rollin-Martinet, S.; Lemoine, P.; Gascoin, F.; Kaltzoglou, A.; Vaqueiro, P.; Powell, A. V.; Guilmeau, E. Thermoelectric Materials: A New Rapid Synthesis Process for Nontoxic and High-Performance Tetrahedrite Compounds. J. Am. Ceram. Soc. 2016, 99 (1), 51-56.

(3) Harish, S.; Sivaprahasam, D.; Battabyal, M.; Gopalan, R. Phase Stability and Thermoelectric Properties of $\mathrm{Cu}_{10.5} \mathrm{Zn}_{1.5} \mathrm{Sb}_{4} \mathrm{~S}_{13}$ Tetrahedrite. J. Alloys Compd. 2016, 667, 323-328.

(4) Greul, E.; Petrus, M. L.; Binek, A.; Docampo, P.; Bein, T. Highly Stable, Phase Pure $\mathrm{Cs}_{2} \mathrm{AgBiBr}_{6}$ Double Perovskite Thin Films for Optoelectronic Applications. J. Mater. Chem. A 2017, 5 (37), 19972-19981.

(5) Hashem, H. M.; Hamed, M. H. Preparation Parameters Optimization and Structure Investigation of Multiferroic Bismuth Ferrite. Mater. Chem. Phys. 2018, 211, 445-451.

(6) Vigier, J.-F.; Freis, D.; Pöml, P.; Prieur, D.; Lajarge, P.; Gardeur, S.; Guiot, A.; Bouëxière, D.; Konings, R. J. M. Optimization of Uranium-Doped Americium Oxide Synthesis for Space Application. Inorg. Chem. 2018, 57 (8), 4317-4327.

(7) Le Tonquesse, S.; Verastegui, Z.; Huynh, H.; Dorcet, V.; Guo, Q.; Demange, V.; Prestipino, C.; Berthebaud, D.; Mori, T.; Pasturel, M. Magnesioreduction Synthesis of Co-Doped $\beta-\mathrm{FeSi}_{2}$ : Mechanism, Microstructure, and Improved Thermoelectric Properties. ACS Appl. Energy Mater. 2019, 2 (12), 8525-8534.

(8) Le Tonquesse, S.; Alleno, É.; Demange, V.; Prestipino, C.; Rouleau, O.; Pasturel, M. Reaction Mechanism and Thermoelectric Properties of $\mathrm{In}_{0.22} \mathrm{Co}_{4} \mathrm{Sb}_{12}$ Prepared by Magnesiothermy. Mater. Today Chem. 2020, 16, 100223.

(9) Lyu, T.; Dorenbos, P. Vacuum-Referred Binding Energies of Bismuth and Lanthanide Levels in $\mathrm{ARE}(\mathrm{Si}, \mathrm{Ge}) \mathrm{O}_{4}(\mathrm{~A}=\mathrm{Li}, \mathrm{Na} ; \mathrm{RE}=$ $\mathrm{Y}, \mathrm{Lu}$ ): Toward Designing Charge-Carrier-Trapping Processes for Energy Storage. Chem. Mater. 2020, 32 (3), 1192-1209.

(10) Ban, V.; Sadikin, Y.; Lange, M.; Tumanov, N.; Filinchuk, Y.; Černý, R.; Casati, N. Innovative in Situ Ball Mill for X-ray Diffraction. Anal. Chem. 2017, 89, 13176-13181.

(11) Kohlmann, H. Looking into the Black Box of Solid-State Synthesis. Eur. J. Inorg. Chem. 2019, 4174-4180.

(12) Cordova, D. L. M.; Johnson, D. C. Synthesis of Metastable Inorganic Solids with Extended Structures. ChemPhysChem 2o20, 21, 1345-1368.

(13) Norby, P. Hydrothermal Conversion of Zeolites: An in Situ Synchrotron X-Ray Powder Diffraction Study. J. Am. Chem. Soc. 1997, 119 (22), 5215-5221.

(14) McCallum, R. W.; Yan, J. Q.; Rustan, G. E.; Mun, E. D.; Singh, Y.; Das, S.; Nath, R.; Bud'Ko, S. L.; Dennis, K. W.; Johnston, D. C.; Canfield, P. C.; Kramer, M. J.; Kreyssig, A.; Lograsso, T. A.; 
Goldman, A. I. In Situ High Energy X-Ray Synchrotron Diffraction Study of the Synthesis and Stoichiometry of LaFeAsO and $\mathrm{LaFeAsO}_{1-\mathrm{x}} \mathrm{F}_{\mathrm{y}}$. J. Appl. Phys. 2009, 105 (12).

(15) Simmance, K.; Sankar, G.; Bell, R. G.; Prestipino, C.; Beek, W. Van. Tracking the Formation of Cobalt Substituted ALPO-5 Using Simultaneous in Situ X-Ray Diffraction and X-Ray Absorption Spectroscopy Techniques. Phys. Chem. Chem. Phys. 2010, 12 (3), 559-562.

(16) Halasz, I.; Puškarić, A.; Kimber, S. A. J.; Beldon, P. J.; Belenguer, A. M.; Adams, F.; Honkimäki, V.; Dinnebier, R. E.; Patel, B.; Jones, W.; Štrukil, V.; Friščić, T. Real-Time in Situ Powder X-Ray Diffraction Monitoring of Mechanochemical Synthesis of Pharmaceutical Cocrystals. Angew. Chemie Int. Ed. 2013, 52 (44), 11538-11541.

(17) Friščić, T.; Halasz, I.; Beldon, P. J.; Belenguer, A. M.; Adams, F.; Kimber, S. A. J.; Honkimäki, V.; Dinnebier, R. E. Real-Time and in Situ Monitoring of Mechanochemical Milling Reactions. Nat. Chem. 2013, 5 (1), 66-73.

(18) Bøjesen, E. D.; Jensen, K. M. Ø.; Tyrsted, C.; Lock, N.; Christensen, M.; Iversen, B. B. In Situ Powder Diffraction Study of the Hydrothermal Synthesis of ZnO Nanoparticles. Cryst. Growth Des. 2014, 14 (6), 2803-2810.

(19) Ragon, F.; Horcajada, P.; Chevreau, H.; Hwang, Y. K.; Lee, U.-H.; Miller, S. R.; Devic, T.; Chang, J.-S.; Serre, C. In Situ EnergyDispersive X-Ray Diffraction for the Synthesis Optimization and Scale-up of the Porous Zirconium Terephthalate UiO-66. Inorg. Chem. 2014, 53 (5), 2491-2500.

(20) Andersen, H. L.; Christensen, M. In Situ Powder X-Ray Diffraction Study of Magnetic $\mathrm{CoFe}_{2} \mathrm{O}_{4}$ Nanocrystallite Synthesis. Nanoscale 2015, 7 (8), 3481-3490.

(21) Andrieux, J.; Gardiola, B.; Dezellus, O. Synthesis of Ti Matrix Composites Reinforced with TiC Particles: In Situ Synchrotron X-Ray Diffraction and Modeling. J. Mater. Sci. 2018, 53 (13), 9533-9544.

(22) Cosby, M. R.; Mattei, G. S.; Wang, Y.; Li, Z.; Bechtold, N.; Chapman, K. W.; Khalifah, P. G. Salt Effects on Li-Ion Exchange Kinetics of $\mathrm{Na}_{2} \mathrm{Mg}_{2} \mathrm{P}_{3} \mathrm{O}_{9} \mathrm{~N}$ : Systematic in Situ Synchrotron Diffraction Studies. J. Phys. Chem. C 2020, 124 (12), 6522-6527.

(23) Hansen, T. C.; Kohlmann, H. Chemical Reactions Followed by in Situ Neutron Powder Diffraction. Zeitschrift fur Anorg. und Allg. Chemie 2014, 640 (15), 3044-3063.

(24) Paul, T.; Singh, A.; Littrell, K. C.; Ilavsky, J.; Harimkar, S. P. Crystallization Mechanism in Spark Plasma Sintered Bulk Metallic Glass Analyzed Using Small Angle Neutron Scattering. Sci. Rep. 2020, 10 (1), 1-11.

(25) Gorria, P.; Garitaonandia, J. S.; Pizarro, R.; MartínezBlanco, D.; Campo, J.; Plazaola, F. Crystallisation and Polymorphic Transformations in $\mathrm{Fe}-\mathrm{Zr}$ Amorphous Alloys Obtained by High-Energy Ball Milling. Phys. B Condens. Matter 2004, 350 (1-3), E1075-E1077.

(26) Redfern, S. A. T.; Harrison, R. J.; O’Neill, H. S. C.; Wood, D. R. R. Thermodynamics and Kinetics of Cation Ordering in $\mathrm{MgAl}_{2} \mathrm{O}_{4}$ Spinel up to $1600{ }^{\circ} \mathrm{C}$ from in Situ Neutron Diffraction. Am. Mineral. 1999, 84 (3), 299-310.

(27) Ok, K. M.; Lee, D. W.; Smith, R. I.; O'Hare, D. TimeResolved in Situ Neutron Diffraction under Supercritical Hydrothermal Conditions: A Study of the Synthesis of $\mathrm{KTiOPO}_{4}$. J. Am. Chem. Soc. 2012, 134 (43), 17889-17891.

(28) Rao, R. P.; Sharma, N.; Peterson, V. K.; Adams, S. Formation and Conductivity Studies of Lithium Argyrodite Solid Electrolytes Using In-Situ Neutron Diffraction. Solid State Ionics 2013, 230 (C), 72-76.

(29) Winkler, B.; Wilson, D. J.; Vogel, S. C.; Brown, D. W.; Sisneros, T. A.; Milman, V. In Situ Observation of the Formation of TiC from the Elements by Neutron Diffraction. J. Alloys Compd. 2007, 441 (1-2), 374-380.

(30) Tomota, Y.; Tokuda, H.; Adachi, Y.; Wakita, M.; Minakawa,
N.; Moriai, A.; Morii, Y. Tensile Behavior of TRIP-Aided MultiPhase Steels Studied by in Situ Neutron Diffraction. Acta Mater 2004, 52 (20), 5737-5745.

(31) Gharghouri, M. A.; Weatherly, G. C.; Embury, J. D.; Root, J. Study of the Mechanical Properties of Mg-7.7 at.\% Al by in-Situ Neutron Diffraction. Philos. Mag. A 1999, 79 (7), 1671-1695.

(32) McIntosh, S.; Vente, J. F.; Haije, W. G.; Blank, D. H. A.; Bouwmeester, H. J. M. Oxygen Stoichiometry and Chemical Expansion of $\mathrm{Ba}_{0.5} \mathrm{Sr}_{0.5} \mathrm{Co}_{0.8} \mathrm{Fe}_{4} \mathrm{O}_{3-\delta}$ - Measured by in Situ Neutron Diffraction. Chem. Mater. 2oo6, 18 (8), 2187-2193.

(33) Latroche, M.; Notten, P. H. L.; Percheron-Guégan, A. In Situ Neutron Diffraction Study of Solid Gas Desorption of NonStoichiometric $\mathrm{AB}_{5}$ Type Hydrides. J. Alloys Compd. 1997, 253-254, 295-297.

(34) Ozawa, M.; Loong, C.-K. In Situ X-Ray and Neutron Powder Diffraction Studies of Redox Behavior in $\mathrm{CeO}_{2}$-Containing Oxide Catalysts. Catal. Today 1999, 50 (2), 329-342.

(35) Kamazawa, K.; Aoki, M.; Noritake, T.; Miwa, K.; Sugiyama, J.; Towata, S. I.; Ishikiriyama, M.; Callear, S. K.; Jones, M. O.; David, W. I. F. In-Operando Neutron Diffraction Studies of Transition Metal Hydrogen Storage Materials. Adv. Energy Mater. 2013, 3 (1), 39-42.

(36) Dolotko, O.; Senyshyn, A.; Mühlbauer, M. J.; Nikolowski, K.; Ehrenberg, H. Understanding Structural Changes in NMC LiIon Cells by in Situ Neutron Diffraction. J. Power Sources 2014, 255, 197-203.

(37) Colin, J.-F.; Godbole, V.; Novák, P. In Situ Neutron Diffraction Study of $\mathrm{Li}$ Insertion in $\mathrm{Li}_{4} \mathrm{Ti}_{5} \mathrm{O}_{12}$. Electrochem. commun. 2010, 12 (6), 804-807.

(38) Aktekin, B.; Valvo, M.; Smith, R. I.; Sørby, M. H.; Lodi Marzano, F.; Zipprich, W.; Brandell, D.; Edström, K.; Brant, W. R. Cation Ordering and Oxygen Release in $\mathrm{LiNi}_{0.5-\mathrm{x}} \mathrm{Mn}_{1.5+\mathrm{x}} \mathrm{O}_{4-\mathrm{y}}$ (LNMO): In Situ Neutron Diffraction and Performance in Li Ion Full Cells. ACS Appl. Energy Mater. 2019, 2 (5), 3323-3335.

(39) Didier, C.; Pang, W. K.; Guo, Z.; Schmid, S.; Peterson, V. K. Phase Evolution and Intermittent Disorder in Electrochemically Lithiated Graphite Determined Using in Operando Neutron Diffraction. Chem. Mater. 2020, 32 (6), 2518-2531.

(40) Grguric, B. A.; Harrison, R. J.; Putnis, A. A Revised Phase Diagram for the Bornite-Digenite Join from in Situ Neutron Diffraction and DSC Experiments. Mineral. Mag. 200o, 64 (2), 213231.

(41) Vaqueiro, P.; Powell, A. V.; Hull, S.; Keen, D. A. PressureInduced Phase Transitions in Chromium Thiospinels. Phys. Rev. $B$ 2001, 63 (6), 641061-641066.

(42) Engin, T. E.; Powell, A. V.; Hull, S. A High Temperature Diffraction-Resistance Study of Chalcopyrite, $\mathrm{CuFeS}_{2}$. J. Solid State Chem. 2011, 184 (8), 2272-2277.

(43) Engin, T. E.; Hull, S.; Powell, A. V. Structural Effects on the Electronic Properties of $\mathrm{TlCu}_{7-\delta} \mathrm{S}_{4}$ Investigated by DiffractionResistance Measurements. Zeitschrift fur Anorg. und Allg. Chemie 2012, 638 (15), 2565-2570.

(44) Kaltzoglou, A.; Vaqueiro, P.; Barbier, T.; Guilmeau, E.; Powell, A. V. Ordered-Defect Sulfides as Thermoelectric Materials. J. Electron. Mater. 2014, 43 (6), 2029-2034.

(45) Barbier, T.; Lemoine, P.; Gascoin, S.; Lebedev, O. I.; Kaltzoglou, A.; Vaqueiro, P.; Powell, A. V.; Smith, R. I.; Guilmeau, E. Structural Stability of the Synthetic Thermoelectric Ternary and Nickel-Substituted Tetrahedrite Phases. J. Alloys Compd. 2015, 634, 253-262.

(46) Lemoine, P.; Bourgès, C.; Barbier, T.; Nassif, V.; Cordier, S.; Guilmeau, E. High Temperature Neutron Powder Diffraction Study of the $\mathrm{Cu}_{12} \mathrm{Sb}_{4} \mathrm{~S}_{13}$ and $\mathrm{Cu}_{4} \mathrm{Sn}_{7} \mathrm{~S}_{16}$ Phases. J. Solid State Chem. 2017, 247, 83-89.

(47) Yang, Z.; PradoGonjal, J.; Phillips, M.; Lan, S.; Powell, A.; Vaqueiro, P.; Gao, M.; Stobart, R.; Chen, R. Improved Thermoelectric Generator Performance Using High Temperature 
Thermoelectric Materials. In SAE Technical Paper Series; 2017; Vol. 1.

(48) Lemoine, P.; Pavan Kumar, V.; Guélou, G.; Nassif, V.; Raveau, B.; Guilmeau, E. Thermal Stability of the Crystal Structure and Electronic Properties of the High Power Factor Thermoelectric Colusite $\mathrm{Cu}_{26} \mathrm{Cr}_{2} \mathrm{Ge}_{6} \mathrm{~S}_{32}$. Chem. Mater. 2020, 32 (2), 830-840.

(49) Rodríguez-Carvajal, J. Recent Advances in Magnetic Structure Determination by Neutron Powder Diffraction. Phys. $B$ Condens. Matter 1993, 192 (1-2), 55-69.

(5o) Roisnel, T.; Rodríguez-Carvajal, J. WinPLOTR: A Windows Tool for Powder Diffraction Pattern Analysis. Mater. Sci. Forum 2001, 378-381 (1), 118-123.

(51) Yund, R. A.; Kullerud, G. Thermal Stability of Assemblages in the Cu-Fe-S System. J. Petrol. 1966, 7 (3), 454-488.

(52) Pavan Kumar, V.; Barbier, T.; Lemoine, P.; Raveau, B.; Nassif, V.; Guilmeau, E. Crucial Role of Selenium for Sulphur Substitution in the Structural Transitions and Thermoelectric Properties of $\mathrm{Cu}_{5} \mathrm{FeS}_{4}$ Bornite. Dalt. Trans. 2017, 46 (7), 2174-2183.

(53) Kanazawa, Y.; Koto, K.; Morimoto, N. Bornite $\left(\mathrm{Cu}_{5} \mathrm{FeS}_{4}\right)$ : Stability and Crystal Structure of the Intermediate Form. Can. Mineral. 1978, 16 (3), 397-404.

(54) Guélou, G.; Powell, A. V.; Vaqueiro, P. Ball Milling as an Effective Route for the Preparation of Doped Bornite: Synthesis, Stability and Thermoelectric Properties. J. Mater. Chem. C 2015, 3 (40), 10624-10629.

(55) Bernstein, L. R. Renierite, $\mathrm{Cu}_{10} \mathrm{ZnGe}_{2} \mathrm{Fe}_{4} \mathrm{~S}_{16}-\mathrm{Cu}_{11} \mathrm{GeAsFe}_{4} \mathrm{~S}_{16}$ : A Coupled Solid Solution Series. Am. Mineral. 1986, 71 (1-2), 210221.

(56) Wintenberger, M. Etude de La Structure Cristallographique et Magnetique de $\mathrm{Cu}_{2} \mathrm{FeGeS}_{4}$ et Remarque Sur la Structure Magnetique de $\mathrm{Cu}_{2} \mathrm{MnSnS}_{4}$. Mater. Res. Bull. 1979, 14 (9), 1195-1202.

(57) Stephens, P. W. Phenomenological Model of Anisotropic Peak Broadening in Powder Diffraction. J. Appl. Crystallogr. 1999, 32 (2), 281-289.

(58) Bernstein, L. R.; Reichel, D. G.; Merlino, S. Renierite Crystal
Structure Refined from Rietveld Analysis of Powder NeutronDiffraction Data. Am. Mineral. 1989, 74 (9-10), 1177-1181.

(59) Gialanella, S.; Girardi, F.; Ischia, G.; Lonardelli, I.; Mattarelli, M.; Montagna, M. On the Goethite to Hematite Phase Transformation. J. Therm. Anal. Calorim. 2010, 102 (3), 867-873.

(6o) Calamiotou, M.; Lampakis, D.; Zhigadlo, N. D.; Katrych, S.; Karpinski, J.; Fitch, A.; Tsiaklagkanos, P.; Liarokapis, E. Local Lattice Distortions vs. Structural Phase Transition in $\mathrm{NdFeAsO}_{1-}$ ${ }_{x} \mathrm{~F}_{\mathrm{x}}$. Phys. C Supercond. its Appl. 2016, 527, 55-62.

(61) Paradis-Fortin, L.; Guélou, G.; Pavan Kumar, V.; Lemoine, P.; Prestipino, C.; Merdrignac-Conanec, O.; Durand, G. R.; Cordier, S.; Lebedev, O. I.; Guilmeau, E. Structure, Microstructure and Thermoelectric Properties of Germanite-Type $\mathrm{Cu}_{22} \mathrm{Fe}_{8} \mathrm{Ge}_{4} \mathrm{~S}_{32}$ Compounds. J. Alloys Compd. 2020, 831, 154767.

(62) Pavan Kumar, V.; Paradis-Fortin, L.; Lemoine, P.; Le Caër, G.; Malaman, B.; Boullay, P.; Raveau, B.; Guélou, G.; Guilmeau, E. Crossover from Germanite to Renierite-Type Structures in $\mathrm{Cu}_{22-\mathrm{x}} \mathrm{Zn}_{\mathrm{x}} \mathrm{Fe}_{8} \mathrm{Ge}_{4} \mathrm{~S}_{32}$ Thermoelectric Sulfides. ACS Appl. Energy Mater. 2019, 2 (10), 7679-7689.

(63) Bourgès, C.; Bouyrie, Y.; Supka, A. R.; Al Rahal Al Orabi, R.; Lemoine, P.; Lebedev, O. I.; Ohta, M.; Suekuni, K.; Nassif, V.; Hardy, V.; Daou, R.; Miyazaki, Y.; Fornari, M.; Guilmeau, E. HighPerformance Thermoelectric Bulk Colusite by Process Controlled Structural Disordering. J. Am. Chem. Soc. 2018, 140 (6), 2186-2195.

(64) Suekuni, K.; Shimizu, Y.; Nishibori, E.; Kasai, H.; Saito, H.; Yoshimoto, D.; Hashikuni, K.; Bouyrie, Y.; Chetty, R.; Ohta, M.; Guilmeau, E.; Takabatake, T.; Watanabe, K.; Ohtaki, M. AtomicScale Phonon Scatterers in Thermoelectric Colusites with a Tetrahedral Framework Structure. J. Mater. Chem. A 2019, 7 (1), 228-235.

(65) Candolfi, C.; Guélou, G.; Bourgès, C.; Supka, A. R.; Al Rahal Al Orabi, R.; Fornari, M.; Malaman, B.; Le Caër, G.; Lemoine, P.; Hardy, V.; Zanotti, J.-M.; Chetty, R.; Ohta, M.; Suekuni, K.; Guilmeau, E. Disorder-Driven Glasslike Thermal Conductivity in Colusite $\mathrm{Cu}_{26} \mathrm{~V}_{2} \mathrm{Sn}_{6} \mathrm{~S}_{32}$ Investigated by Mössbauer Spectroscopy and Inelastic Neutron. Phys. Rev. Mater. 2020, 4, 025404. 


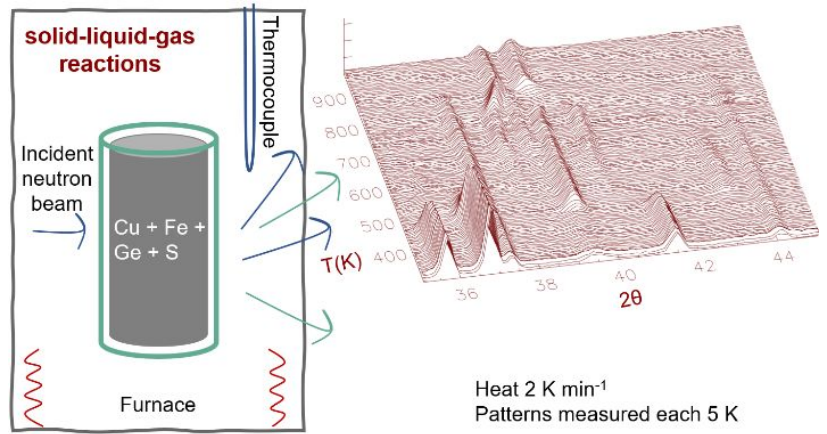

